\title{
Integrované výkaznictví a zveřejňování nefinančních informací v Evropě
}

\section{Vážení čtenáři,}

přestože trendem účetního výkaznictví v posledním desetiletí je zvyšování objemu informací, nejrůznější studie na celoevropské úrovni dokazují, že tyto informace svojí strukturou nevyhovují současným potřebám uživatelů účetních informací. Jaké informace uživatelé ve výročních zprávách očekávají? Uživatelé rozšiřují okruh svých požadavků a ve zvýšené míře se zajímají o nefinanční informace, o sociální a environmentální aspekty ve výročních zprávách. V evropském kontextu by se dalo očekávat, že odpověd' na zvýšené požadavky uživatelů dají účetní směrnice. Účetní směrnice, kterými se účetní jednotky v otázce zveřejňování informací řídí, však dostatečně účinně neregulují zveřejňování právě nefinančních informací. Povinnost zveřejňování nefinančních informací stanovená směrnicemi o účetnictví nebyla dostatečně jasná. Nefinanční informace pravidelně zveřejňuje pouze omezený počet velkých společností v Evropské unii a kvalita zveřejněných informací se velmi liší. Odlišnosti vedou ke ztíženému pochopení a srovnání pozice a výkonnosti společností zúčastněnými stranami. Některé členské státy vypracovaly vnitrostátní právní předpisy, které jdou nad rámec požadavků směrnic o účetnictví. Vnitrostátní požadavky se však podstatně liší, což vede k obtížím pří porovnávání společností napříč vnitřním trhem. Společnosti by měly mít systém pro začleňování sociálních a environmentálních otázek do své podnikatelské činnosti a strategie. Nefinanční transparentnost je tudíž základním prvkem jakékoli politiky v oblasti sociální odpovědnosti podniků. Evropská komise vypracovala návrh na vylepšení požadavků na zveřejňování nefinančních informací již v roce 2011. Součástí návrhu byl požadavek, aby vyšší transparentnost neměla za následek zvýšení administrativní zátěže. Menší společnosti mají při shromažd'ování a analýze informací více obtíží. V souladu se zásadou ,přednost malým a středním podnikům“ by se požadavky na zveřejňování podle této směrnice neměly vztahovat na společnosti, jejichž velikost se nachází pod vymezenou hranicí. Pokud jde o velké společnosti, je třeba, aby nefinanční informace na úrovni Evropské unie byly zveřejňovány přístupnějším, užitečnějším a soudržnějším způsobem, nebot' činnost těchto společností často zasahuje celou Evropskou unii a má význam pro investory a jiné zúčastněné strany na celém vnitřním trhu. Kromě harmonizovaného požadavku na soudržné informace společné na celém jednotném trhu by členské státy nicméně měly mít určitou míru flexibility, pokud jde o stanovení dalších požadavků na podávání zpráv. Z toho důvodu je změna směrnic o účetnictví nejvhodnějším právním nástrojem, nebot' členským státům dává určitou flexibilitu. Změna směrnic rovněž zajistí, aby obsah a forma navrhovaného opatření Evropské unie nepřekračovaly rámec toho, co je nezbytné a přiměřené pro dosažení regulačního cíle.

$\mathrm{V}$ letošním roce bylo několikaleté úsilí $\mathrm{v}$ této oblasti završeno vydáním směrnice o zveřejňování nefinančních informací a informací týkajících se rozmanitosti rrídících a dozorčích orgánů některými velkými společnostmi a skupinami. Před schválením této směrnice, Evropský parlament přijal dvě rezoluce v roce 2013, které uznávají důležitost transparentnosti environmentálních a sociálních záležitostí. Obě se týkaly sociální odpovědnosti společností první zdůraznila transparentní a odpovědné chování společností a udržitelný rozvoj a druhá se týkala prosazování společenských zájmů a udržitelné a podporující obnově.

Společnosti, kterých se směrnice týká, budou $\mathrm{v}$ souladu $\mathrm{s}$ touto směrnicí zveřejňovat informace o používaných pravidlech, riziku a environmentálních záležitostech, sociálních aspektech a aspektech, které se týkají zaměstnanců, lidských práv, protikorupčními opatřeními a otázkami praní špinavých peněz a současně posílení transparentnosti tím, že se zvýší 
rozmanitost řídících a dozorčích orgánů společností. Očekává se, že se zavedením těchto požadavků zlepší transparentnost společností a zveřejňování významných nefinančních informací. Tvrdí se, že ze zvýšené transparentnosti budou mít užitek společnosti, investoři a společnost vůbec. Zavedení tohoto požadavku je důležité pro konkurenceschopnost Evropy a zvýšení pracovních př́ležitostí. Tento požadavek však platí jen pro největší evropské společnosti a společnosti ve skupině.

Nalézt řešení pomocí transpozice směrnice do právního řádu členského státu Evropské unie je způsob poněkud zdlouhavý. Investoři a další zainteresované strany požadují na společnostech informace minimálně za každé účetní období, u společností na regulovaných trzích s ještě kratší frekvencí. Lhůta pro transpozici směrnice je rok 2016. Bylo by řešením zavedení tzv. „integrovaného výkaznictví? „Co je integrované výkaznictví?“ prrípadně „Co by mělo být integrované výkaznictví?" Integrované účetnictví jako nový přístup ve zveřejňování informací společnostmi se objevuje v letech 2009-2010. V zásadě existují dva možné př́istupy k obsahu integrovaného výkaznictví: bud' povinné účetní výkaznictví a povinný výkaz o správě a řízení společnosti plus dobrovolně zveřejňovaná zpráva o udržitelném rozvoji (tzv. sustainability report) nebo tzv. „sběrné výkaznictvi““ bez vazeb uvnitř a mezi jednotlivými výkazy. Mělo by být integrované výkaznictví kombinací IFRS (International Financial Reporting Standards - Mezinárodní standardy účetního výkaznictví), a výkaznictví zaměřené na udržitelný rozvoj? Je otázkou jak integrované výkaznictví vůbec chápat. V této otázce existuje dilema, zdali integrované výkaznictví má být v souladu se všemi nebo jen s většinou požadavků koncepčního rámce Mezinárodní rady pro integrované výkaznictví (International Integrated Reporting Council, IIRC). Toto rozhodnutí by vedlo k tomu, že integrované výkazy by se sestavovaly spíše pro účely rozhodování a pro akcionáře než pro všechny zainteresované strany. Další otázkou zůstává, zdali má vzniknout globální tvůrce standardu integrovaného výkaznictví a jaká bude úloha IIRC? Dalším aspektem integrovaného výkaznictví je jeho důvěryhodnost a př́istupy $\mathrm{k}$ řešení důvěryhodnosti. Př́́kladem řešení $\mathrm{v}$ Německu je návrh na zabezpečení důvěryhodnosti výkaznictví prostřednictvím povinnosti zveřejnit auditované integrované výkazy v souladu s IIRC standardy, které jsou schválené Evropsku unií a které jsou následně kontrolovatelné a vynutitelné Německým výborem pro vynutitelnost integrovaného výkaznictví.

V oblasti integrovaného účetnictví je nutné řešit následující otázky proto, aby integrované výkaznictví bylo udržitelné:

1. Jasně definovat integrované výkaznictví.

2. Přetvořit systém výuky a vzdělávání, aby obsahoval témata integrovaného výkaznictví.

3. Tolerovat rozmanitost forem výkaznictví v praxi, tolerovat vazby také k jiným výborům než IIRC atp.

4. Rozdělit práce mezi IIRC, IASB (International Accounting Standards Board), GRI (Global Reporting Initiative - nezisková organizace tvořící standardy pro zpracování zprávy o udržitelném rozvoji), popř. v rámci Evropské unie.

Je však nutné se ptát „Je integrované výkaznictví relevantní pro investory?“ Účetní výkaznictví se považuje za primární komunikaci s investory a analytiky. $Z$ investorského hlediska je zapotřebí zlepšit právě provázanost mezi finančními a nefinančními informacemi, které ovlivňují společnost. Dále je potřeba zvýšit spolehlivost vykazovaných environmentálních, sociálních údajů a informací o správě a vedení společností. $\mathrm{K}$ dosažení tohoto cíle je potřebné vymyslet a zavést takovou strategii výkaznictví, která bude zaměřena na finanční výsledky a zároveň postihne všechny relevantní faktory, včetně nefinančních. První kroky směrem k tvorbě strategie výkaznictví podnikla expertní skupina založená IIRC. Expertní skupina v současné době sestavila několik otázek a vyzvala veřejnost, aby se podílela na odpovědích. Odpovědi 
PŘEDMLUVA - Žárová, M.: Integrované výkaznictví a zveřejňování nefinančnich informací v Evropě.

budou vyhodnoceny a IIRC bude se závěry pracovat. Mezi otázkami, kterými se expertní skupina v současné době zabývá, je také otázka zdali koncepční rámec IIRC poskytuje vhodná kritéria k posouzení odpovědnosti nebo kritérium pro stanovení nákladu. $Z$ uvedeného vyplývá, že zvyšování objemu zveřejňovaných informací má svoje hranice a řešení není jednoznačné.

doc. Ing. Marcela Žárová, CSc.

proděkanka pro zahraniční vztahy Fakulta financí a účetnictví Vysoká škola ekonomická v Praze 